\title{
Predictors and outcomes of customer loyalty in the South African leafy vegetable market
}

\author{
Phineas Mbango \\ Vincent Makhubela \\ College of Economic and Management Sciences \\ Department of Marketing and Retail Management \\ University of South Africa, Pretoria - South Africa
}

\begin{abstract}
Keywords
Commitment, Communication, Loyalty, Product quality, Repurchase, Satisfaction, Trust, Word-ofmouth
\end{abstract}

\begin{abstract}
The purpose of this research paper was to examine if product quality, trust, customer satisfaction and communication have a positive influence on customer loyalty. Furthermore, the research intended to determine the outcomes of customer loyalty in the Gauteng province of the South Africa leafy vegetable market. Data was collected through purposive and convenience sampling technique using self-administered questionnaires with the assistance of research assistants. A total of 367 respondents completed the questionnaires. A structural equation modelling technique using the partial least squares (PLS) approach was used to analyse the data. The results show that of the selected antecedents of customer loyalty examined, only customer satisfaction was identified as a significant determinant. With regard to the outcomes, the results show that commitment, word-of-mouth and repurchase intention are outcomes of customer loyalty in the South African leafy vegetable market. The implications for both academic and managerial decision makers are outlined.
\end{abstract}

Corresponding author: Phineas Mbango

Email addresses for the corresponding author: mbangp@unisa.ac.za

First submission received: $7^{\text {th }}$ May 2018

Revised submission received: $18^{\text {th }}$ August 2018

Accepted: $12^{\text {th }}$ November 2018

1 Introduction

According to Vesel and Zabkar (2010), Theron, Terblanche and Boshoff (2010) and Segarra-Moliner, Moliner-Tena and Sánchez-Garcia (2013), commitment, trust and satisfaction are commonly believed to be important elements to build effective relationships. Nonetheless, as noted by Mpinganjira, Bogaards, Svensson and Mysen (2014) and Mbango (2015), some scholars do not agree to the aforementioned because these three concepts are inter-linked, and studies were conducted in different industries. However, Farrelly and Quester (2005) discuss that customer loyalty is caused by trust and commitment, similarly, Kantsperger and Kunz (2010) and Taleghani, Choobeh and Mousavian (2011) maintain that customer loyalty is a root for trust, while Hau and Ngo (2012) argue that satisfaction is caused by trust. Wali, Wright and Uduma (2015) contend that from an African perspective, leafy vegetable customer loyalty and commitment are the outcomes of customer satisfaction. In this study, the researcher's position that commitment is an outcome of customer loyalty and customer satisfaction is a predictor of customer loyalty.

Apart from the aforementioned constructs, this study posits product quality, trust, customer satisfaction and communication as determinants of customer loyalty in the South African leafy vegetable market. Repeat purchase (intention), word-of-mouth and commitment are viewed as outcomes of customer loyalty.

Moreover, although understanding customer loyalty is a prerequisite to promoting a viable leafy market sector, most studies on the antecedents and outcomes of customer loyalty are based on manufacturer-supplier relationships (Mpinganjira, et al., 2014; Mbango, 2015) without studies done on specific industries. Therefore, there is a dearth of research on the antecedents and outcomes of customer

www.jbrmr.com A Journal of the Academy of Business and Retail Management (ABRM) 
loyalty in the leafy vegetable sector. This study sets to improving our understanding on this issue by examining the antecedents and outcomes of customer loyalty in the South African leafy vegetable market. The findings of this study have implications for theory and managerial decisions aimed at promoting customer loyalty in the South African leafy vegetable market.

\subsection{Background information}

Agriculture is the strength of many African economies (Balarane \& Oladele, 2012). About 86 percent of rural people in Africa depend on agriculture as a choice of living and it provides employment for approximately 1.3 billion landless workers and small farmers in the world (Tita, 2008). Agriculture plays an essential role in the society in terms of fighting poverty, providing food, well-being and building the African economic growth. In South Africa the agricultural sector is the sophisticated profitable farming industry (Antwi \& Seahlodi, 2011), which is predominantly operated by white farmers (Senyolo, Chaminuka, Makhura \& Belete, 2009). However, black farmers operate most subsistence-based farming in the deep rural areas (Antwi \& Seahlodi, 2011).

Wehmeyer and Rose (1983) highlight that in South Africa there are more than 100 different plants that are used as leafy vegetables. African people mutually call these plants cheke (Tsonga), imifino (isiZulu, isiXhosa) or morogo (Sesotho, SePedi), translated as leafy vegetables in English. Leafy vegetables are harvested from fallow, cultivated fields or wild fields (Van Rensburg, Averbeke, Slabbert, Faber, Van Jaarsveld, Van Heerden, Wenhold \& Oelofse, 2007). Native leafy vegetables are vegetable species that are genuinely indigenous to various region. The usage of leafy vegetables in South Africa is as old as the history of modern man (Van Rensburg et al., 2007). South African agricultural research focused on monocropping systems and large-scale commercial farmers in the previous decade (Vorster, Van Rensburg, Van Zijl \& Venter, 2005).

\section{Literature review, hypotheses development and research framework}

\subsection{Overview of studies on customer loyalty}

As defined by Javalgi and Moberg (1997:165), customer loyalty is a "consideration of the amount of buying for a given trademark which measures the frequency of buying". Customer loyalty is linked to a positive relationship maintenance between the business and customers, by means of consistent purchases of leafy vegetables from the same business. According to Cardozo (1965) and Oliver (1999), customer loyalty is the benefit that follows providing excellent customer satisfaction. Customer loyalty refers to a customers' commitment to continued buying of their favourite product, constantly over time and not switching to a competitor's product (Mostert, Petzer \& Weideman, 2016). Businesses desire to satisfy their existing customers by forming customer loyalty programmes such as VIP club members through longterm relationships in order to increase their business profits. Customer loyalty is linked to customers' sentimentality that utilisation is pleasant as the product performance exceeds their expected needs. Customer loyalty occurs when customers sustain their affiliation with a certain business about repeated purchases (Huang, Tsang \& Zhou, 2011). Suki (2017) opines that customer satisfaction has an influence on customer loyalty.

Satisfied customers have a tendency of repeating their purchases or recommending products to their family members and friends and stay loyal to leafy vegetables consumption (Suki, 2017). Satisfied customers recommend products via word-of-mouth.

\subsection{Research model and hypotheses development}

Consistent with the literature, the current research study proposes a research model (Figure 1), which identifies product quality, trust, satisfaction and communication as direct predictors of customer loyalty and word-of-mouth, commitment and repeat purchase as outcomes of customer loyalty in the South African leafy vegetable market. 


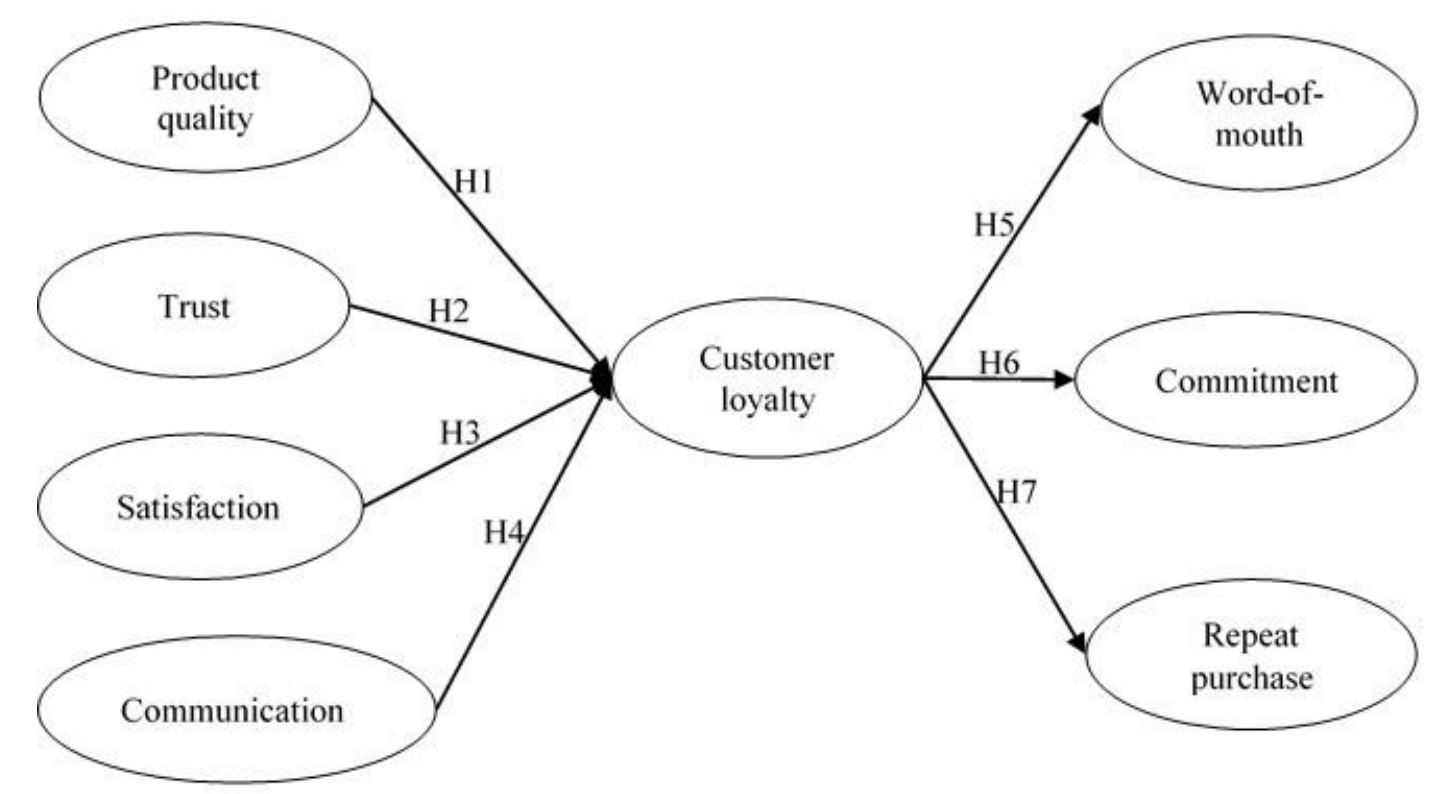

Figure 1: Proposed research model for predictors and outcomes of customer loyalty The following sections discuss the hypotheses in the proposed research model.

\subsubsection{Product quality}

Product quality is linked to the performance of the product that may have an impact on the requirements of the customer product on designing the packaging, warranties and features of the product. High quality products obtain better customer acceptance and further will result in satisfaction, loyalty and repurchase intentions (Chang \& Fong, 2010). The customer's attitude toward leafy vegetables influence the customer's purchase intention (Suki, 2016). The quality of products such as leafy vegetables is influenced by social value, because the quality of leafy vegetables may lead to customers' satisfaction.

Previous studies confirm that quality of product is positively linked with customer loyalty and satisfaction (Park, Robertson \& Wu, 2004; Chang \& Tu, 2005; Martenson 2007; Chang \& Fong, 2010). Many scholars, such as Mayer (2013), Norazah (2013) and Suki (2016) highlight that customers' decision-making processes are influenced by knowledge of the quality of leafy vegetables. Therefore, the proposed hypothesis is:

H1: Product quality has a positive influence on customer loyalty.

\subsubsection{Trust}

Morgan and Hunt (1994), discuss trust as the level of self-assurance in an exchange partner's integrity and reliability, which plays an essential role in building marketing relationships for a business. Trust develops when a business satisfies the needs of the customer (Rampl, Eberhardt, Schütte \& Kenning, 2012). Trust is a sensible expectation when fiduciary obligation, excellent performance and accountability are forthcoming (See-To \& Ho, 2014).

Customers trust is significant in producing, building and maintaining confidence in leafy vegetable safety (De Jonge, Frewer, Van Trijp, Renes, De Wit \& Timmers, 2004). Norazah (2013) highlights that customers are willing to buy leafy vegetables that are not harmful to the environment. It is difficult for customers to measure food safety related risks and to gain trust because they have to use old-fashioned methods such as smelling or tasting the leafy vegetables (Chen, 2008). Customers' trust within the leafy vegetables industry and building relationships plays an important role in influencing the customers purchasing behaviour (Ariyawardana, Ganegodage \& Mortlock, 2017).

The second hypothesis is:

$\mathrm{H} 2$ : Trust has a positive influence on customer loyalty. 


\subsubsection{Customer satisfaction}

Customer satisfaction is measured based on the results of a provided service, irrespective of whether the provided service has met the customers' needs and expectations (Orel \& Kara, 2014). It is observed as the outcome of the customers' post-purchase assessments of tangible and intangible qualities and as the cause of customer loyalty (Krystallis \& Chrysochou, 2014). Customer satisfaction derives from experience with a product and it positively influences customer loyalty such as customer relationship management (CRM) quality (Nyadzayo \& Khajehzadeh, 2016). Customer satisfaction denotes that customer needs, expectations and wishes are met during the product or service period, providing a means for customer loyalty and repeat repurchasing (Suki, 2016). Customer satisfaction is the measurement where a customer experiences a pre-purchasing prospect from the product that results in satisfaction after the act of purchasing the product (Suki, 2016). Based on the environmental setting, customer satisfaction is linked to how customers feel about the leafy vegetables consumption and how leafy vegetables meet and exceed the customer's needs (Suki, 2016). Both fresh leafy vegetables and good service lead to customer satisfaction and customer repeat purchase intention (Nyadzayo \& Khajehzadeh, 2016).

Previous studies by Fornell (1992); Gremler and Brown (1996); Zeithaml, Berry and Parasuraman (1996) and Seiders, Voss, Grewal and Godfrey (2005) highlight that good influence of customer satisfaction is the result of attitudinal loyalty, customer referrals, service usage, relationship length and repeat purchase intentions. Businesses benefit from high customer satisfaction and increase customer loyalty because of customer satisfaction (Shi \& Chen, 2011). Previous studies conclude that customer satisfaction influences customer loyalty (Burns \& Neisner, 2006; He \& Song, 2008; Chang \& Fong 2010; Mensah, 2010; Tee, Thoo, Amran, Rosman \& Huam, 2012; and Norazah, 2013). However, a study conducted by Zhang (2008) argues that businesses that satisfy their customers do not always attain loyal customers. Thus, customer satisfaction does not always affirm customer loyalty (Shi \& Chen, 2011).

This study assesses whether customer satisfaction results in customer loyalty for South African suppliers of leafy vegetables. Loyal customers assist the business to lower their marketing costs (Nyadzayo \& Khajehzadeh, 2016).

This leads to the next hypotheses of the study:

H3: Customer satisfaction has a positive influence on customer loyalty.

\subsubsection{Communication}

Alhabash, Almutairi, Lou and Kim (2018) define communication as the outcome of the human motivational system that interacts with channelling a message. Communication is the process that delivers ideas, information and attitudes to a diversified and sizable people by means of a medium developed for that purpose (Huang, Liang \& Tsai, 2018). Communicating with customers enable the key elements of its service offering (Merlo, Eisingerich, Auh \& Levstek, 2018). Leafy vegetable suppliers/ sellers who communicate with their customers normally attempt to persuade the customers' behaviour and consistently remind their customers about the key elements of its service offering. Communication is essential because it enable the business to determine the success or failure of marketing leafy vegetables in South Africa (Adekunle, 2013).

The fourth proposed hypothesis is:

H4: Communication has a positive influence on customer loyalty.

\subsubsection{Word-of-mouth}

Word-of-mouth (WOM) is defined as an informal, person-to-person communication between a noncommercial communicator and a non-commercial receiver concerning a product, a company or a service (Cantallops \& Salvi, 2014). WOM is a cheap form of marketing in terms of physical costs. At the same time, what customers decide to communicate with other customers is informed partially by social risks (De Angelis, Bonezzi, Peluso, Rucker \& Costabile, 2012). The purpose of customer WOM is to increase the buying behaviour of customers and to motivate the retransmission of WOM (Baker, Donthu \& Kumar, 2016). WOM is a way of understanding how things operate (Williams-Forson, 2014; Baker et al., 2016). This means understanding how customers regularly share information, opinions and news with others. For instance, customers normally have chats about service they experienced or become enthusiastic about an excellent service they received or complain about the product/service. They further gossip about the 
company, co-workers, political issues and even start rumours (Berger, 2014). WOM may comprise of people discussing product-related issues or sharing product-related content. WOM literally includes word-of-mouth, face-to-face direct recommendations or word-of-mouse (online discussion) (Berger, 2014). It has a vast influence on customer purchasing behaviour (Berger, 2014). WOM, amongst others, often is used as a source of information for individuals that are interested in a certain product (Cantallops \& Salvi, 2014). WOM is an important strategy to assess and develop personal narratives (Westby, 2018).

In essence, loyal customers are likely to have a positive WOM that may influence customers' purchasing behaviour. In this manner, when leafy vegetable customers experience excellent customer service, they usually recommend the leafy vegetable to their friends or family through WOM. Thus, the next hypothesis is:

H5: Customer loyalty has a positive influence on word-of-mouth referrals.

\subsubsection{Commitment}

Commitment is perceived as a key element in building customer loyalty (Hur, Kim \& Kim, 2013). Moorman, Zaltman and Deshpande (1992) define commitment as a continuing desire to maintain a good relationship. Commitment is perceived as when the business believes there is an ongoing relationship with the customer and it is vital, but maximum effort is required to maintain it (Sun \& Chen, 2014).

Customer commitment does not only depend on the quality and quantity of the behavioural hints that customers give, but also on the communication between the customer and the salesperson (Homburg, Bornemann \& Kretzer, 2014). Customer commitment is another essential driver of repeat repurchase intentions (Keiningham, Frennea, Aksoy, Buoye \& Mittal, 2015). Rubinson \& Baldinger (1996) argue that commitment is a reliable predictor for customer loyalty, and it has a great influence on customers' behaviour. This argument is generally based on and drawn from the western developed countries. However, from an African perspective, leafy vegetable customer loyalty and commitment is the outcome of customer satisfaction (Wali, Wright \& Uduma, 2015); customer satisfaction mediates customer commitment and it appears to have a positive impact on future intentions (Sun \& Chen, 2014).

In this study, commitment is seen as an outcome of customer loyalty. The hypothesis for this notion is:

H6: Customer loyalty has a positive influence on commitment.

\subsubsection{Repeat purchase (retention)}

Repeat purchase refers to the probability that a customer may continue to buy products from the same seller (Chiu, Wang, Fang \& Huang, 2014). Initially, repeat purchase signifies the possibility that prospective customers may purchase from the seller for the first time (Chiu et al., 2014). Repeat purchase is important for the success and survival for any business (Chiu et al., 2014). It is imperative that businesses to know the repeat purchase rate for repeatedly purchased products (Rosenzweig, Grinstein \& Ofek, 2016). The repeat purchase intentions are caused by benefits that come with the product (Baker et al., 2016). Li, Browne and Wetherbe (2006) argue that satisfied customers do not always predict customers' repeat purchase. However, trust is used as a predictor for repeat purchase (Hsu, Chang \& Chuang, 2015). Based on the reviewed literature, the following hypothesis is established:

H7: Customer loyalty has a positive influence on repeat purchase.

\section{Research methodology}

The quantitative approach using the survey method was used. Data were collected using a selfadministered questionnaire, with the help of research assistants, that was based on a seven-point Likert scale.

\subsection{Population and sample}

The respondents of the study were customers of leafy vegetable suppliers in Gauteng province, South Africa. The respondents were customers conveniently and purposively selected in the Gauteng province of South Africa, mainly in the city of Johannesburg. 400 questionnaires were distributed and 367 were usable, representing 92 percent. The sample size was deemed good for analysis using Roscoe's (1975) way of calculating sample sizes, which proposes that sample sizes should be more than 300 and less than 500 for good research. 


\subsection{Data collection procedure}

Purposive and convenience sampling were used to collect data from respondents using a selfadministered questionnaire with the help of eight research assistants. These assistants were trained on how to complete the questionnaire. The targeted respondents were customers who had bought leafy vegetables in the central business district (CBD) of Johannesburg. The suppliers included farmers, retail shops, fruit and vegetable shops, hawkers and supermarkets. The research assistants administered the questionnaires to customers carrying leaf vegetables. They had to ask for permission from the concerned participant if they were willing to complete the questionnaire while the research assistant waited.

\subsection{Measurement and questionnaire design}

The research constructs used were obtained from existing validated measures. The items of scales were articulated to meet the context of the study. All measurement scales were based on a seven-point Likert scale ranging from one (strongly disagree) to seven (strongly agree). The construct quality was adapted from Suki (2016), trust was adapted from Mpinganjira et al. (2014), communication adopted from Mbango (2015), satisfaction was adopted from Mbango (2015), customer loyalty was adopted from Suki (2016), word-of-mouth referrals was adopted from Baker et al. (2016), repeat purchase (retention) was adapted from Mpinganjira et al. (2014) and commitment was adopted from Morgan and Hunt (1994).

The questionnaire consisted of three sections: Section A contained the introduction; Section B contained the demographic profile and Section C contained the constructs for the study.

\section{Data analysis and results discussions}

\subsection{Descriptive statistics}

Data analysis for descriptive statistics was carried out using the Statistical Package for Social Sciences (SPSS) (version 24). The results of the demographic statistics of the sample are presented in Table 1.

Table 1: Demographic statistics of sample

\begin{tabular}{llll}
\hline & & Frequency & Percent \\
\hline Gender & Male & 156 & 42.5 \\
& Female & 211 & 57.5 \\
Age & $<30$ & 144 & 39.2 \\
& $30-39$ & 136 & 37.1 \\
& $40-49$ & 67 & 18.3 \\
& $>50$ & 20 & 5.4 \\
\hline
\end{tabular}

According to the results, of the 367 participants of the study $156(42.5 \%)$ of them are males and 211 $(57.5 \%)$ are female. This shows that female participation in the study was higher than male. This is expected given that the South African population comprises more females than males. With regard to age composition of the sample, the results show that over one-third of the sample (39.2\%) is below the age of 30. Furthermore, the results of the demographic profile of the sample further indicate that over two-thirds of the participants (76.3\%) is below the age 40. Participants between 40-49 form 18.3 percent of the sample and those above age 50 comprise 5.4 percent of the sample.

Descriptive statistics using mean and standards deviation was computed for the constructs of the study. The results of this analysis are presented in Table 2.

Table 2: Descriptive statistics of constructs

\begin{tabular}{lll}
\hline Construct & Mean & Std. Deviation \\
\hline Quality & 5.95 & .825 \\
Trust & 5.66 & .960 \\
Communication & 5.51 & .963 \\
Satisfaction & 5.69 & .838 \\
Loyalty & 5.62 & .818 \\
Word-of-mouth & 5.61 & 1.062 \\
Repurchase intention & 6.07 & .887 \\
Commitment & 5.93 & .992 \\
\hline
\end{tabular}


The results show that the overall mean for most of the constructs is above five, with a range between 5.51 to 6.07. Given that the items of each construct are measured on a seven-point scale, a mean value of five indicates that most respondents generally agree with the items measuring the constructs. The standard deviation values are low with .825 being the lowest and 1.062 being the highest. These low standard deviation values generally indicate a narrow spread of the data point around the mean.

\subsection{Structural equation modelling}

A structural equation modelling technique using the partial least squares (PLS) approach was used to analyse the data further, with SmartPLS version 3.2.7 software (Ringle, Wende \& Becker, 2015). Following the two-step procedure recommended by Anderson and Gerbing (1988), the measurement model was first evaluated for its validity and, subsequently, the structural model was assessed to test the significance of the paths and coefficient of determination $\left(R^{2}\right)$ in the outcome variable.

\subsubsection{Measurement model analysis}

A confirmatory factor analysis approach was used to assess validity of the measurement model. In assessing the validity of the measurement model, convergent validity and discriminant validity were established. In assessing the convergent validity of the measurement model, standardised factor loading, composite reliability (CR) and average variance extracted (AVE) were utilised. To achieve convergent validity, it is recommended that the factor loadings should be significant and exceed 0.5 , the CR should be greater than 0.7 and AVE should be greater than 0.5 (Hair, Black, Babin, \& Anderson, 2010). The results of the convergent validity of the measurement model are presented in Table 3.

Table 3: Convergent factor validity

\begin{tabular}{|c|c|c|c|c|}
\hline & Factor loadings & Composite reliability & $\begin{array}{l}\text { Average factor } \\
\text { extracted }\end{array}$ & t-value \\
\hline Commitment & & 0.879 & 0.708 & \\
\hline COM1 & 0.832 & & & 8.909 \\
\hline COM2 & 0.845 & & & 9.296 \\
\hline COM3 & 0.848 & & & 9.480 \\
\hline Communication & & 0.839 & 0.566 & \\
\hline CMN1 & 0.705 & & & 7.524 \\
\hline CMN2 & 0.711 & & & 7.814 \\
\hline CMN3 & 0.800 & & & 9.554 \\
\hline CMN4 & 0.788 & & & 9.607 \\
\hline Customer loyalty & & 0.839 & 0.636 & \\
\hline LOY1 & 0.846 & & & 12.768 \\
\hline LOY2 & 0.842 & & & 13.774 \\
\hline LOY3 & 0.695 & & & 10.341 \\
\hline Product quality & & 0.868 & 0.568 & \\
\hline QUA1 & 0.789 & & & 7.109 \\
\hline QUA2 & 0.764 & & & 7.539 \\
\hline QUA3 & 0.719 & & & 5.779 \\
\hline QUA4 & 0.677 & & & 7.121 \\
\hline QUA5 & 0.812 & & & 7.593 \\
\hline Repurchase intention & & 0.841 & 0.638 & \\
\hline RIN1 & 0.795 & & & 8.671 \\
\hline RIN2 & 0.817 & & & 10.912 \\
\hline RIN3 & 0.785 & & & 8.319 \\
\hline Satisfaction & & 0.837 & 0.507 & \\
\hline SAT1 & 0.722 & & & 8.268 \\
\hline SAT2 & 0.714 & & & 10.15 \\
\hline SAT3 & 0.664 & & & 7.737 \\
\hline SAT4 & 0.678 & & & 7.015 \\
\hline SAT5 & 0.777 & & & 11.142 \\
\hline Trust & & 0.855 & 0.596 & \\
\hline TRU1 & 0.808 & & & 10.732 \\
\hline TRU2 & 0.806 & & & 10.72 \\
\hline
\end{tabular}




\begin{tabular}{llll}
\hline & & & \\
\hline TRU3 & 0.781 & & 8.868 \\
TRU4 & 0.687 & 0.772 & 0.538 \\
Word-of-mouth & & & \\
WOM1 & 0.862 & & 5.489 \\
WOM2 & 0.754 & & 4.310 \\
WOM3 & 0.551 & & 1.152 \\
\hline
\end{tabular}

The results presented in Table 3 suggest that all the factors are significant at 0.001 (t-values greater 2.575). The factor loadings range between 0.551 to 0.848 thus exceeding the 0.5 recommended threshold. Moreover, the lowest CR estimate computed for the measurement model is 0.772 . This exceeds the 0.7 threshold. The AVEs are also above the 0.5 threshold with 0.507 being the lowest. Put together, these estimates generally confirm the convergent validity of the measurement model.

After confirming the convergent validity of the measurement model, discriminant validity was assessed using the Fornell-Larcker technique (Fornell \& Larcker, 1981). According to this technique, discriminant validity is achieved when the square root of the AVEs is greater than the inter-factor correlations. The results of the discriminant validity of the measurement model for this study are presented in the Table 4 . The results presented in the table show that the square root of the AVEs (bold diagonal values) are greater than inter-factor correlations (values below the bold diagonal values). This suggests that the condition for discriminant validity is met thus confirming the discriminant validity of the measurement model.

Table 4: Discriminant validity of the measurement model

\begin{tabular}{|c|c|c|c|c|c|c|c|c|}
\hline Constructs & 1 & 2 & 3 & 4 & 5 & 6 & 7 & 8 \\
\hline Commitment & 0.841 & & & & & & & \\
\hline Communication & 0.425 & 0.752 & & & & & & \\
\hline Customer loyalty & 0.418 & 0.496 & 0.798 & & & & & \\
\hline Product quality & 0.439 & 0.363 & 0.425 & 0.754 & & & & \\
\hline Repeat purchase & 0.73 & 0.416 & 0.478 & 0.503 & 0.799 & & & \\
\hline Satisfaction & 0.439 & 0.587 & 0.652 & 0.441 & 0.489 & 0.712 & & \\
\hline Trust & 0.516 & 0.552 & 0.491 & 0.484 & 0.541 & 0.559 & 0.772 & \\
\hline Word-of-mouth & 0.477 & 0.31 & 0.253 & 0.353 & 0.548 & 0.347 & 0.465 & 0.734 \\
\hline
\end{tabular}

Bold diagonal values are square roots of the AVEs

\subsubsection{Structural model analysis}

After confirming the validity of the measurement model, the structural model was assessed to test the hypotheses proposed for the study. To determine the path significance of the relationships between the construct in the research model, a PLS bootstrapping method using 500 subsamples was conducted using the SmartPLS 3.2.7 software. The results of the analysis are presented in figures 2 and 3. 
Figure 2: Structural model with path coefficients

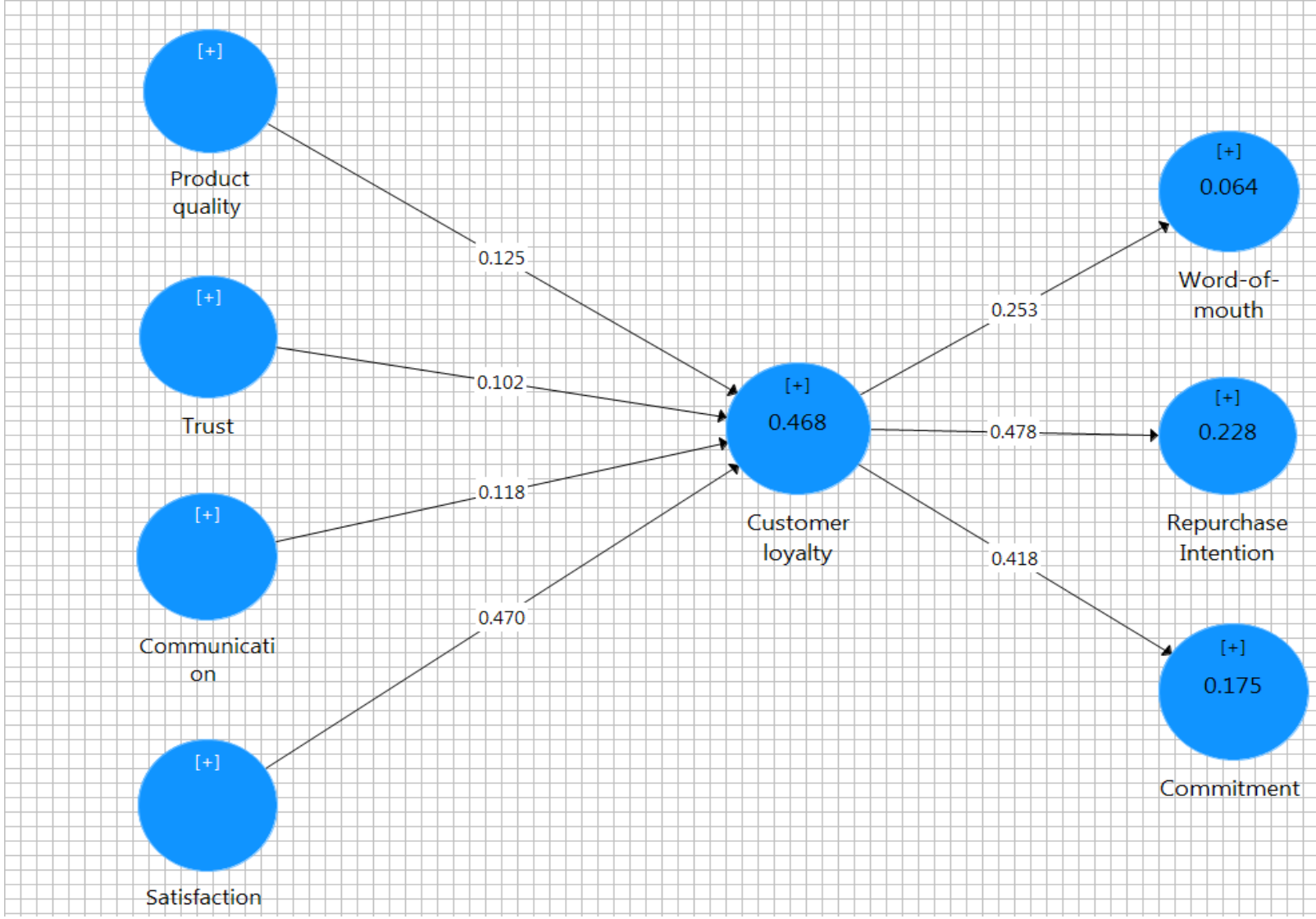

Figure 3: Structural model with T-values for path significance

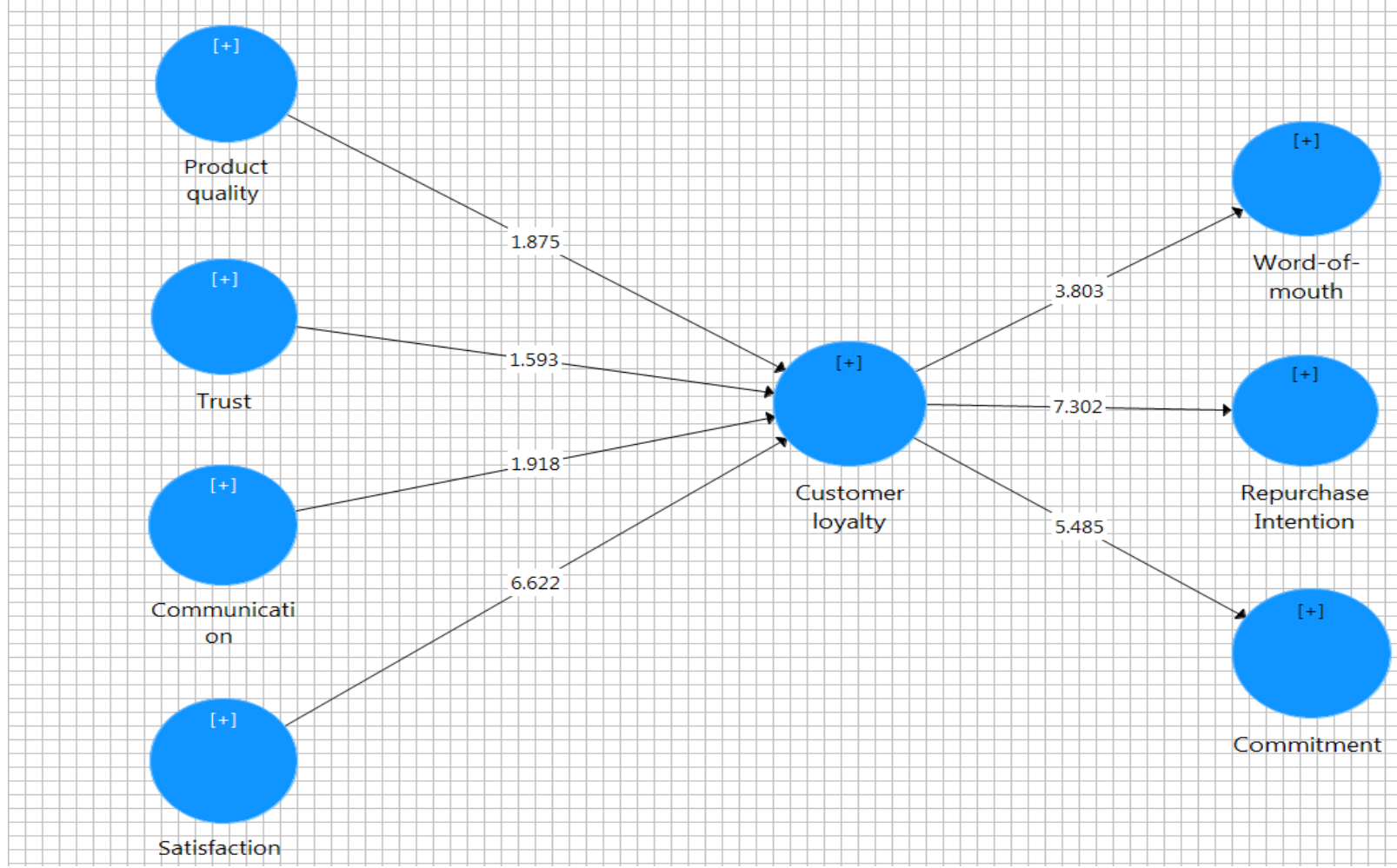


The results of the structural model suggest that the effect of product quality on customer loyalty is not significant $(\beta=0.125 ; \mathrm{t}>1.875)$, therefore, H1 is not supported. Similar results were also found for the relationship between trust and customer loyalty. The empirical results suggest that the impact of trust on customer loyalty to leafy vegetable suppliers is not statistically significant $(\beta=0.102 ; t=1.593)$, therefore, $\mathrm{H} 2$ is not supported. The analysis further suggests that communication is not a significant predictor of customer loyalty $(\beta=0.118 ; t=1.918)$. However, the results found that customers' satisfaction with leafy vegetable suppliers has a significant positive effect on their loyalty to leafy vegetable suppliers $(\beta=0.470$; $\mathrm{t}=6.622$ ), hence, $\mathrm{H} 4$ is statistically supported. In terms of the outcomes of customer satisfaction, the empirical analysis of the results show that customer loyalty significantly and positively predicts their word-of-mouth communication $(\beta=0.253 ; \mathrm{t}=3.803)$, repurchase intention $(\beta=0.478 ; \mathrm{t}=7.302)$ and commitment $(\beta=0.418 ; \mathrm{t}=5.485)$. These results provide statistical support for $\mathrm{H} 5, \mathrm{H} 6$ and $\mathrm{H} 7$.

The research model explains 46.8 percent of the variance in customer loyalty, 6.4 percent of the variance in word-of-mouth, 22.8 percent of the variance in repurchase intention and 17.5 percent of the variance in customer commitment to leafy vegetable suppliers.

\section{Discussions and conclusions}

Most studies, Farrelly and Quester (2005), Kantsperger and Kunz (2010), Taleghani, Choobeh and Mousavian (2011) on customer loyalty point to the fact that trust, communication and product quality are essential determinants of customer loyalty but the empirical findings of this study does not support this notion. In this study, the impact of trust on customer loyalty to leafy vegetable suppliers is not statistically significant, communication is not a significant predictor of customer loyalty, and the effect of product quality on customer loyalty is also not significant.

Trust is used as a predictor of repeat purchase (Hsu, Chang \& Chuang, 2015), where in terms of the outcomes of customer satisfaction, results of this study stipulate that customer loyalty significantly predicts repurchase intention. In addition, most studies Vesel and Zabkar (2010), Theron, Terblanche and Boshoff (2010) and Segarra-Moliner, Moliner-Tena and Sánchez-Garcia (2013), position commitment as an essential determination of customer loyalty. The empirical findings of this study indicate that commitment is an outcome of customer loyalty. Word-of-mouth and repeat purchase are also outcomes of customer loyalty. Customers tend to purchase leafy vegetables continuously after they have built loyalty. The explanation for the difference in the findings maybe because most of the previous studies on trust, commitment, product quality, communication and satisfaction are based on European samples and on business-to-business settings, Mpingangira et al. (2014). This study was based in Gauteng province, South Africa, where the majority of the population are black Africans who may have different views. This calls for more research on specific sectors and different population samples.

Marketing managers of leafy vegetable suppliers (farmers, retail shops, fruit and vegetable shops and street hawkers) have to pay particular attention to customer satisfaction in order to achieve outcomes such as word-of-mouth referrals, commitment and repeat purchase, all of which are essential ingredients in the business success. Therefore, marketing managers of leafy vegetables have to devise strategies that ensure customer needs are met and exceeded. Particular attention needs to be paid to excellent customer service.

\section{Limitations and direction for future research}

This study has a major contribution to both theory and practice. However, the use of nonprobability sampling may limit generalisation of the findings, but some academics have found that nonprobability sampling may be good in situations where there is a need to get responses from qualified respondents. The sample of the population can be seen as a limiting factor as respondents were only from Gauteng province, South Africa mainly the CBD of Johannesburg. Again, it can be urged that Johannesburg represents the business centre of Africa, therefore, its findings can be generalised.

This study lays a good foundation for academics to do further research in testing theories, which are grounded in European samples on African samples. 


\section{References}

Adekunle, O.O. (2013). An investigation of challenges facing home gardening farmers in South Africa: A case study of three villages in Nkokonbe municipality Eastern Cape Province. Journal of Agricultural Science, 6(1), 102-109.

Alhabash, S., Almutairi, N., Lou, C. \& Kim, W. (2018). Pathways to virality: psychophysiological responses preceding likes, shares, comments, and status updates on Facebook. Media Psychology, 1-21.

Anderson, J.C. \& Gerbing, D.W. (1988). Structural equation modeling in practice: A review and recommended twostep approach. Psychological bulletin, 103(3): 411-423.

De Angelis, M.D., Bonezzi, A., Peluso, A.M., Rucker, D.D. \& Costabile, M. (2012). On braggarts and gossips: A selfenhancement account of word-of-mouth generation and transmission. Journal of Marketing Research, 49(4), 551563.

Antwi, M. \& Seahlodi, P. (2011). Marketing constraints facing emerging small-scale pig farmers in Gauteng province, South Africa. Journal of Human Ecology, 36(1), 37-42.

Ariyawardana, A., Ganegodage, K. \& Mortlock, M.Y. (2017). Consumers' trust in vegetable supply chain members and their behavioural responses: A study based in Queensland, Australia. Food Control, 73, 193-201.

Baker, A.M., Donthu, N. \& Kumar, V. (2016). Investigating how word-of-mouth conversations about brands influence purchase and retransmission intentions. Journal of Marketing Research, 53(2), 225-239.

Balarane, A. \& Oladele, O.I. (2012). Awareness and use of agricultural market information among small scale farmers in Ngaka Modiri Molema District of North West Province. Life Science Journal, 9(3), 57-62.

Berger, J. (2014). Word of mouth and interpersonal communication: A review and directions for future research. Journal of Consumer Psychology, 24(4), 586-607.

Burns, D. \& Neisner, L.N. (2006). Customer satisfaction in a retail setting: The contribution of emotion. International Journal of Retail \& Distribution Management, 34(1), 49-66.

Chang C.H. \& Tu, C.Y. (2005). Exploring store image, customer satisfaction, and customer loyalty relationship: Evidence from Taiwanese hypermarket industry. Journal of American Academic Business, 7,197-202.

Chang, N.J. \& Fong, C.M. (2010). Green product quality, green corporate image, green customer satisfaction, and green customer loyalty. Journal of Business and Management, 4, 2836-2844.

Cantallops, A.S. \& Salvi, F. (2014). New consumer behavior: A review of research on eWOM and hotels. International Journal of Hospitality Management, 36, 41-51.

Cardozo, R.N. (1965). An experimental study of customer effort, expectation and satisfaction. Journal of Marketing Research, 2(8), 244-249.

Chen, M.F. (2008). Consumer trust in food safety: A multidisciplinary approach and empirical evidence from Taiwan. Risk Analysis, 28, 1553-1569.

Chiu, C.M., Wang, E.T., Fang, Y.H. \& Huang, H.Y. (2014). Understanding customers' repeat purchase intentions in B2C e-commerce: The roles of utilitarian value, hedonic value and perceived risk. Information Systems Journal, 24(1), 85-114.

De Jonge, J., Frewer, L., Van Trijp, H., Renes, R.J., De Wit, W. \& Timmers, J. (2004). Monitoring consumer confidence in food safety: An exploratory study. British Food Journal, 106(10/11), 837-849.

Farrelly, F.J. \& Quester, P.G. (2005). Examining important relationship constructs of the focal sponsorship exchange. Industrial Marketing Management, 34(3), 211-219.

Fornell, C. (1992). A national customer satisfaction barometer: The Swedish experience. The Journal of Marketing, 6-21.

Fornell, C. \& Larcker, D.F. (1981). Structural equation models with unobservable variables and measurement error: Algebra and statistics. Journal of Marketing Research, 18(3), 382-388.

Gremler, D.D. \& Brown, S. (1996). Service Loyalty: Its nature, importance and implications. Advancing Service Quality: A Global Perspective, 5, 171-180.

Hair J.F. Jr., Black, W.C, Babin, B.J. \& Anderson, R.E. (2010). Multivariate data analysis. (7th edition). Upper Saddle River, NJ: McGraw-Hill.

Hau, L. \& Ngo, L. (2012). Relationship marketing in Vietnam: An empirical study. Asia Pacific Journal of Marketing and Logistics, 24(2), 222-235.

He, Y. \& Song, H. (2008). A mediation model of tourists' repurchase intentions for packaged tour services. Journal of Travel Research, 47, 317-331.

Homburg, C., Bornemann, T. \& Kretzer, M. (2014). Delusive perception-antecedents and consequences of salespeople's misperception of customer commitment. Journal of the Academy of Marketing Science, 42(2), 137153.

Hsu, M.H., Chang, C.M. \& Chuang, L.W. (2015). Understanding the determinants of online repeat purchase intention and moderating role of habit: The case of online group buying in Taiwan. International Journal of Information Management, 35(1), 45-56.

Huang M, Cai F, Tsang, A.S.L. \& Zhou, N. (2011). Making your online voice loud: The critical role of WOM information. European Journal of Marketing, 45, 1277-1297. 
Huang, W.L., Liang, J.C. \& Tsai, C.C. (2018). Exploring the relationship between university students' conceptions of and approaches to learning mass communication in Taiwan. The Asia-Pacific Education Researcher, 27(1), 43-54.

Hur, W.-M., Kim, H.K. \& Kim, H. (2013). Investigation of the relationship between service values and loyalty behaviors under high commitment. Service Business, 7(1), 103-119.

Javalgi, R.G. \& Moberg, C.R. (1997). Service loyalty: Implications for service providers. Journal of Services Marketing, 11(3), 165-179.

Kantsperger, R. \& Kunz, W.H. (2010). Consumer trust in service companies: A multiple mediating analysis. Managing Service Quality, 20(1), 4-25.

Keiningham, T.L., Frennea, C.M., Aksoy, L., Buoye, A. \& Mittal, V. (2015). A five-component customer commitment model: Implications for repurchase intentions in goods and services industries. Journal of Service Research, 18(4), 433-450.

Krystallis, A. \& Chrysochou, P. (2014). The effects of service brand dimensions on brand loyalty. Journal of Retail Consumer Service, 21(2), 139-147.

Li, D., Browne, G.J. \& Wetherbe, J.C. (2006). Why do internet users stick with a specific web site? A relationship perspective. International Journal of Electronic Commerce, 10(4), 105-141.

Martenson, R. (2007). Corporate brand image, satisfaction and store loyalty: A study of the store as a brand, store brands and manufacturer brands. International Journal of Retail E Distribution Management, 35, 544-555.

Mayer, A. (2013). Education and the environment: An international study. International Journal of Sustainable Development \& World Ecology, 20, 512-519.

Mbango, P. (2015). Causes and outcomes of customer satisfaction in business-to-business markets relationship marketing in the South African Cement Manufacturing Industry. Journal of Governance and Regulation, 4(4), 399407.

Mensah, A. (2010). Customer satisfaction in the banking industry: A comparative study of Spain and Ghana. Unpublished PhD dissertation.

Merlo, O., Eisingerich, A., Auh, S. \& Levstek, J. (2018). The benefits and implementation of performance transparency: The why and how of letting your customers 'see through' your business. Business Horizons, 61(1), 73-84.

Moorman, C., Zaltman, G. \& Deshpande, R. (1992). Relationships between providers and users of market research: The dynamics of trust within and between organizations. Journal of Marketing Research, 29, 314-328.

Morgan, R.M. \& Hunt, S.D. (1994). The commitment-trust theory of relationship marketing. Journal of Marketing, 58, 20-38.

Mostert, P.G., Petzer, D.J. \& Weideman, A. (2016). The interrelationships between customer satisfaction, brand loyalty and relationship intentions of Generation Y consumers towards smart phone brands. South African Journal of Business Management, 47(3), 25-34.

Mpinganjira, M., Bogaards, M., Svensson, G. \& Mysen, T. (2014). Precursors and outcomes of satisfaction in business relationships: A replication study. Management Dynamics, 23(2), 2-13.

Norazah, M.S. (2013). Green awareness effects on consumer's purchasing decision: Some insights from Malaysia. International Journal Asia Pacific Studies, 9, 49-63.

Nyadzayo, M.W. \& Khajehzadeh, S. (2016). The antecedents of customer loyalty: A moderated mediation model of customer relationship management quality and brand image. Journal of Retailing and Consumer Services, 30, 262270.

Oliver, R.L. (1999). Whence consumer Loyalty? Journal of Direct marketing, 63, 33-44.

Orel, F.D. \& Kara, A., (2014). Supermarket self-checkout service quality, customer satisfaction, and loyalty: Empirical evidence from an emerging market. Journal of Retail Consumer Service, 21(2), 118-129.

Park, J., Robertson, R., Wu, C. (2004). The effect of airline service quality on passengers' behavioural intentions: A Korean case study. Journal Air Transport Management, 10, 435-439.

Rampl, L.V., Eberhardt, T., Schütte, R. \& Kenning, P. (2012). Consumer trust in food retailers: Conceptual framework and empirical evidence. International Journal of Retail and Distribution Management, 40(4), $254-272$.

Ringle, C.M., Wende, S. \& Becker, J.M. 2015. SmartPLS. Boenningstedt: SmartPLS GmbH, http:/ / www.smartpls.com.

Roscoe, J.T. (1975). Fundamental research statistics for the behavioural sciences. (2nd edition). New York: Holt Rinehart \& Winston.

Rosenzweig, S., Grinstein, A. \& Ofek, E. (2016). Social network utilization and the impact of academic research in marketing. International Journal of Research in Marketing, 33(4), 818-839.

Rubinson, J. \& Baldinger, A. (1996). Brand loyalty: The link between attitude and behaviour. Journal of Advertising Research, 36(6).

See-To, E.W.K. \& Ho, K.K.W. (2014). Value co-creation and purchase intention in social network sites: The role of electronic Word-of-mouth and trust: A theoretical analysis. Computers in Human Behavior, 31, 182-189.

Segarra-Moliner, J.R., Moliner-Tena, M.A. \& Sánchez-Garcia, J. (2013). Relationship quality in business to business: A cross-cultural perspective from universities. Marketing Intelligence and Planning, 31(3), 196-215.

www.jbrmr.com A Journal of the Academy of Business and Retail Management (ABRM) 
Seiders, K., Voss, G.B., Grewal, D. \& Godfrey, A.L. (2005). Do satisfied customers really buy more? Examining moderating influences in a retailing context. Journal of Marketing, 69(2), 26- 43.

Senyolo, G.M., Chaminuka, P., Makhura, M.N. \& Belete, A. (2009). Patterns of access and utilization of output markets by emerging farmers in South Africa: Factor analysis approach. African Journal of Agricultural Research, 4(3), 208-214.

Shi, W.H. \& Chen, J.J. (2011). A study of customer loyalty based on switching cost and brand attachment. The Journal of China Universities of Posts and Telecommunications, 18, 136-141.

Suki, N.M. (2016). Green product purchase intention: Impact of green brands, attitude, and knowledge. British Food Journal, 118(12), 2893-2910.

Sun, S.Y. \& Chen, L.S. (2014). Exploring the servicing effectiveness of social media in customers' electronic word of mouth (eWOM). International Journal of Organizational Innovation, 6(3), 63-67.

Taleghani, M., Choobeh, E. \& Mousavian, S. (2011). The role of loyalty dimensions in customer orientation process for new enterprises in tourism industries of Iran. Australian Journal of Business and Management Research, 1(6), 143151.

Tee, C.H, Thoo, A.C, Amran, R, Rosman, M.D. \& Huam, H.T. (2012). The effects of service quality, customer satisfaction on re-patronage intentions of hotel existing customers. Int J Manage Adm Sci. 1:1-6.

Theron, E., Terblanche, N.S. \& Boshoff, C. (2010). Trust, commitment and satisfaction: New perspectives from business-to-business (B2B) financial services relationships in South Africa. Stellenbosch University.

Tita, D.F. (2009). A transaction cost analysis of factors affecting market arrangements in the agroforestry tree product value chain in Cameroon. International Master of Science in Rural Development, 1-131.

Van Rensburg, W.J., Van Averbeke, W., Slabbert, R., Faber, M., Van Jaarsveld, P., Van Heerden, I., Wenhold, F. \& Oelofse, A. (2007). African leafy vegetables in South Africa. Water South Africa, 33(3), 317-326.

Vesel, P. \& Zabkar, V. (2010). Comprehension of relationship quality in the retail environment. Managing Service Quality, 20(3), 213-235.

Vorster, I.H., van Rensburg, W.J., Van Zijl, J.J.B. \& Venter, S.L. (2005). The importance of traditional leafy vegetables in South Africa. Developing African leafy vegetables for improved nutrition, 1-149.

Wali, A.F., Wright, L.T. \& Uduma, I.A. (2015). Customer relationship management for brand commitment and brand loyalty. British Journal of Marketing Studies, 3(4), 45-58.

Wehmeyer, A.S. \& Rose, E.F. (1983). Important indigenous plants used in the Transkei as food supplements. Bothalia, 14(4), 613-615.

Westby, C. (2018). Personal Narratives of children with Down syndrome. Word of Mouth, 29(3), 1-4.

Williams-Forson, P. (2014). I haven't eaten if I don't have my soup and fufu: Cultural preservation through food and foodways among Ghanaian migrants in the United States. Africa Today, 61(1), 68-87.

Zeithaml, V., Berry, L. \& Parasuraman, A. (1996). The behavioral consequences of service quality. Journal of Consumer Marketing, 60, 31-46.

Zhang, C. (2008). Consumer-brand relationship's continuance: An empirical analysis on the campus marketing of mobile phone. Dalian University of Technology. Unpublished Masters dissertation. 